\title{
The Contribution of Career Guidance Service in Public Secondary Schools towards Professional Training: A Case of Magu District, Mwanza
}

\author{
Justine Matiko Alloph, Dr Eustard Tibategeza
}

\author{
St. Augustine University of Tanzania, Tanzania
}

Received: 01 Dec 2021; Received in revised form: 22 Jan 2022; Accepted: 30 Jan 2022

(C2022 The Author(s). Published by TheShillonga. This is an open access article under the CC BY license

(https://creativecommons.org/licenses/by/4.0/)

\begin{abstract}
The study sought to examine the influence of career guidance services provided in public secondary schools on students' choices of future professional training in Magu district, Mwanza-Tanzania. The study was guided by Social Cognitive Career Theory (SCCT) that was developed by Lent, Brown, and Hackett in 1994. The study employed convergent parallel research design under mixed research approach which help in data collection, analysis of data. The sample size was 152 participants, simple randomly sampling was used to select secondary school teachers and form four students from. While purposive sampling was used to select public secondary school leavers in 2020 and head of secondary schools. Quantitative data were collected through questionnaires and analyzed using descriptive statistics with the helper of Statistical Package for Social Science (SPSS) version 21 and presented in frequency, percentages, graphs and charts. Qualitative data were collected through interview and analyzed thematically by creating themes. The study revealed that career guidance service that was provided in public secondary schools was ineffective; hence, making secondary school leavers to join unplanned professional training since it did not contribute to the students' choices of future professional training. The government should ensure provision of career guidance services training to teachers.
\end{abstract}

Keyword-Career guidance services, Professional training, Public secondary school and secondary school leavers.

I. INTRODUCTION AND BACKGROUND TO THE STUDY

Career guidance is an important influence in one's choice of future professional training. An individual enters into planned and right future professional training because of the career guidance service provided in secondary schools.

The aspect of career guidance emerged in the first part of the $20^{\text {th }}$ century in different countries around the world. This started to help students to choose their right future professions and training in their life (Zafar, 2019). A study conducted by Wong and Yuen (2019) shows that the aspect of career guidance started over the last 60 years in Hong Kong with the aim of assisting students in the choice of future professional training. However, due to insufficient and unstructured career guidance service provision in secondary schools, many students have ended up choosing careers of their parents' interests.

In Asia, Karachi, Pakistan, and China, professional choices depend on profession training which an important aspect in students' lives is. Career guidance is highly needed in
Pakistan to promote employment and productivity. According to Yaqoob, Arif, Samad, and Iqbal (2017) the selection of a future profession depends on the effective delivery of career guidance service in secondary schools which provides information on employment opportunities that are available. This shows that effective career guidance is a crucial aspect in career decision making, which finally reduces the rate of unemployment.

Recently, a study conducted in Hong Kong, China, by Wong and Yuen (2019) noted that, despite the establishment of career guidance about sixty years ago, still it remains undeveloped for a long time. The development of career guidance service in secondary schools in Hong Kong has occurred in four phases, the first stage was 1950-1970, second one 1970s-1990, the third phase 1990s-2000 and fourth stage in 2000-2018. Also, Wong and Yuen asserts that career guidance service does not only involve the provision of career knowledge but also guide the students on the future professional training choices which introduce them into the world of work.

Hughes (2017) argues that the development of career guidance system in England has five years of historical 
development although the policy which supports the history was inconsistent with that of the government. According to Hooley (2019), England as part of the United Kingdom, has a unique system on how to provide career guidance service compare to other countries like Scotland, Wales as well as Northern Ireland. However, Hooley comments that Scotland as part of United Kingdom shares some features in the system of career guidance with England.

In Africa, the intensification of education access has resulted in producing more skilled individuals who compete for a limited number of employment opportunities that are available. This situation has led to the rise of career guidance service in secondary schools for the aim of providing career knowledge and skills among the secondary school students (Mabula, 2012). Similarly, Loan and Van (2015) have noted that the high rate of unemployment among the undergraduate students is caused by the wrong choice of their professional training which is a result of ineffective career guidance service in secondary schools.

In East Africa, education career and guidance service (ECGS) have been provided since 2002. Nsamba, Kiweewa, Oonyu, and Otwine (2018) insist that East African countries like Uganda emphasizes on the provision of career guidance services in secondary schools with the aim of guiding students on vocational training and facilitating their transition from education to the employment market. Therefore, in consideration of employment rate in Uganda, it is clear that career service is an important aspect in reducing the rate of unemployment. However, in the recent past, there have been no efforts put in place in providing guidance service among the students. This shows how ineffective career guidance service has been in the country in the recent past (Robert, 2019).

Kenya is among the developing countries in East Africa which provides career guidance service in secondary schools that emphases on the provision of career information and career instruction for the future training. Ineffective career help service in Kenyan secondary school has led to students making wrong career choices, thus resulting in high rates of unemployment Ibrahim (Wambiya, Aloka \& Raburu, 2014). This is because when career information is provided, it directs students to choose professions for certain employment opportunities (Gacohi, Sindabi, \& Chepchieng, 2017).

Nyambuya, and Onyango (2020) have pointed out that in Tanzania there is ineffective career guidance among secondary schools students which leads to wrong selection of subject combinations, thereby resulting in wrong choices of future professional training and finally to unemployment. From what has been explained above, it is plausible to say that the increase in unemployment rate in Tanzania is due to students making wrong choices of their professional training which is due to ineffective career guidance services in secondary schools in the country. From the preliminary study conducted by the researcher in Magu district it's observed that majority of the heads of schools in Magu district emphasize much on the provision of career guidance service in schools. The service provided during teaching and learning process and near final form four examination although most of the secondary school leavers who traced through snowball technique join unplanned professional training which finally lead them to unemployment. Therefore, this study examined the way career guidance service in public secondary schools in Magu district, Mwanza Tanzania contributes to the selection of future professional training among secondary school students.

\section{Statement of the Problem}

The information provided by the international labour organization shows that in Tanzania, the rate of unemployment increased in the years 2018 to 2020. Among the factors which lead to unemployment in the country is the choice of unplanned one's professional training. The goal of career guidance is to prepare students towards making right choices of their future professional training. Heads of schools in Magu district emphasize much on the provision of career guidance service because it is important in the students' choices of future professional training. From the preliminary study conducted in $\mathrm{Mgu}$ district the researcher identified that despite the presence of career guidance service in public secondary schools found in Magu district, students lack ideas on which professions they should join after completing secondary school education whereby most of the school leavers enter into unplanned or wrong professions thereby making them vulnerable to unemployment. In Tanzania, different studies have been carried out on career guidance but few on how it contributes to the future profession training. Therefore, the current study find out the contribution of career guidance services in public secondary schools towards the choices students make in their future professions in Magu district, Tanzania.

\section{Significance of the Study}

The results and recommendations of the study might be important to different groups in education sector including the students, policy makers and education leaders. Since the study provide awareness on the contribution of career guidance services to secondary school students' choices of their future professional training based on their intellectual 
abilities and interests. Moreover the findings and recommendations of the study are important to educational leaders as it they expose the challenges facing teachers in providing career guidance services and the way to handle those challenges.

\section{Theoretical Framework}

This study guided by the Social Cognitive Career Theory (SCCT) which was established by Lent, Brown, and Hackett in 1994. The theory states that individuals make career choices by considering both internal and external factors that have an influence on individuals' goals, selfefficacy, career interests, and future expectations. The Social Cognitive Career Theory is relates to this study due to its argument that the selection of future professional training depends on career guidance, as well as the individual and environmental factors.

\section{RELATED LITERATURE REVIEW}

Zafar (2019) comments that in Pakistan students who had career guidance had no difficulties in making decisions about career choices. Similarly, Jain (2017) argues that there is a direct link between career counselling and guidance with the choice of career to the students. This shows that effective career guidance in secondary schools has influence on students' career choices.

A study conducted in Lebowakgomo District, in Northern Province of South Africa by William (2016) revealed that ineffective career guidance in secondary schools impacted negatively on students' choices of post-secondary school courses and training. Also, the findings revealed that career guidance was not given special attention in secondary schools in South Africa. Therefore, career guidance should be made an important component in subjects offered in secondary schools in order to help the learners to associate what they have learn with the employment opportunities available.

\section{RESEARCH METHODOLOGY}

This study used mixed research approach to get appropriate research findings on the contribution of career guidance service in public secondary schools towards students' choices of professional training in Magu district. Mixed research approach has been explained as the integration of qualitative approach and quantitative approaches in a single study (Azorin, 2016). The use of mixed research approach enabled the researcher to obtain comprehensive information concerning the study problem. This study employed a convergent parallel mixed research design in data collection, analysis and presentation. Convergent parallel design is a method whereby a researcher concurrently administers both qualitative and quantitative research instruments in the same phase (Demir \& Pismek, 2018). Therefore, the researcher collected qualitative and quantitative data concurrently. The use of convergent parallel research design enabled the researcher to collect data concurrently, to acquire a deep and comprehensive information as well as to make a comparison of the qualitative and quantitative information obtained from the field.

\section{Sampling Procedures}

This study employed both probability and non-probability sampling techniques. In the probability sampling, the study used simple random sampling technique to select 59 secondary school teachers and 85 form four students. While purposive sampling was used in non-probability technique to select 4 heads of schools and 4 public secondary school leavers in 2020. Thus make a total of 152 respondents.

\section{Data Collection Methods}

Quantitative data were collected through questionnaire (open ended and close ended question) and analyzed through descriptive statistic with the helper of the Statistical Package for Social Science (SPSS) version 21. The quantitative findings were presented in chapter four through table, charts and graph. The qualitative data were collected through interview and analyzed through thematic analysis and the findings were presented in quotation and narrative form.

\section{FINDINGS AND DISCUSSION}

This chapter focuses on the presentation and discussion of the findings collected from the field. The analysis of the data, its interpretation and discussion of the findings are based the influence of career guidance on students' future professional training choices.

Career Guidance Services in Public Secondary Schools Enable the Students to Choose their Future Professional Training.

This study sought to identify the contribution of career guidance service toward the choice of future professional training. In this objective the findings are presented in Table 1 
Table 1: Teachers' responses on whether career guidance services in secondary schools in influence students' choice of future professional training $(n=59)$.

\begin{tabular}{|c|c|c|c|c|c|c|c|c|c|c|c|}
\hline \multirow[t]{3}{*}{ No } & \multirow[t]{3}{*}{ Statement } & \multicolumn{10}{|c|}{ Response } \\
\hline & & \multicolumn{2}{|c|}{$\mathbf{S A}$} & \multicolumn{2}{|c|}{$\mathbf{A}$} & \multicolumn{2}{|c|}{$\mathbf{N}$} & \multicolumn{2}{|c|}{ D } & \multicolumn{2}{|c|}{ SD } \\
\hline & & $\mathbf{F}$ & $\mathbf{P}$ & $\mathbf{F}$ & $\mathbf{P}$ & $\mathbf{F}$ & $\mathbf{P}$ & $\mathbf{F}$ & $\mathbf{P}$ & $\mathbf{F}$ & $\mathbf{P}$ \\
\hline 1. & $\begin{array}{l}\text { Career guidance services in secondary school } \\
\text { influence career choices }\end{array}$ & 5 & 8.5 & 1 & 1.7 & 2 & 3.4 & 34 & 57.6 & 17 & 28.8 \\
\hline 2. & $\begin{array}{l}\text { Career guidance services enable students to } \\
\text { associate what they have learnt, their ability and } \\
\text { interest with the available job opportunities. }\end{array}$ & 5 & 8.5 & 4 & 6.8 & 4 & 6.8 & 21 & 35.6 & 25 & 42.4 \\
\hline 3. & $\begin{array}{l}\text { Ineffective career guidance services in public } \\
\text { secondary school impact negatively on the } \\
\text { choice of post-secondary school training. }\end{array}$ & 22 & 37.3 & 30 & 50.8 & 3 & 5.1 & 3 & 5.1 & 1 & 1.7 \\
\hline 4. & $\begin{array}{l}\text { The information about careers provided in career } \\
\text { guidance services has greater influence on the } \\
\text { choice of post-secondary training programme. }\end{array}$ & - & - & 3 & 5.1 & 3 & 5.1 & 22 & 37.3 & 31 & 52.5 \\
\hline
\end{tabular}

Source: Field Data, (2021).

Key; SD - Strongly disagree, D - Disagree, N - Neutral, A - Agree, SA - Strongly agree, P - Percentage and F - Frequency

Table 1 displays the responses to the statements which determine whether career guidance service contribute to the choice of future professional training among secondary school leavers. 51 per cent of teachers agreed that ineffective career guidance services in public secondary school impacted negatively on the choice of postsecondary school training while 58 of the teachers disagreed that career guidance services in secondary school influenced career choice. Conversely, 53 per cent of teachers strongly disagreed that the information about career knowledge provided in career guidance services had a greater influence on the choice of post-secondary training programmes whereas 42 per cent of teachers strongly agreed that career guidance services enabled students to associate what they had learnt, their abilities and interests with the present job opportunities.

Table 2: Students Response on Career Guidance Services in Public Secondary Schools enable the choice of Future Professional Training Students Response (85).

\begin{tabular}{|c|c|c|c|c|c|c|c|c|c|c|c|}
\hline \multirow[t]{3}{*}{ No } & \multirow[t]{3}{*}{ Statement } & \multicolumn{10}{|c|}{ Response } \\
\hline & & \multicolumn{2}{|l|}{ SA } & \multicolumn{2}{|l|}{ A } & \multicolumn{2}{|l|}{$\mathbf{N}$} & \multicolumn{2}{|l|}{ D } & \multicolumn{2}{|c|}{ SD } \\
\hline & & $\mathbf{F}$ & $\mathbf{P}$ & $\mathbf{F}$ & $\mathbf{P}$ & $\mathbf{F}$ & $\mathbf{P}$ & $\mathbf{F}$ & $\mathbf{P}$ & $\mathbf{F}$ & $\mathbf{P}$ \\
\hline 1. & $\begin{array}{l}\text { Career guidance services in public secondary } \\
\text { school influence choice of future profession } \\
\text { training. }\end{array}$ & - & - & 1 & 1.2 & 5 & 5.9 & 35 & 41.2 & 44 & 51.8 \\
\hline 2. & $\begin{array}{l}\text { Teachers interact and talk to the students } \\
\text { about the world of work }\end{array}$ & 2.4 & 2 & 7 & 1.2 & 7 & 8.2 & 43 & 50.6 & 32 & 37.6 \\
\hline 3. & $\begin{array}{l}\text { The information I got from my teacher about } \\
\text { career helped me to choose my subjects of } \\
\text { specialization }\end{array}$ & 2 & 2.4 & - & - & 6 & 7.1 & 35 & 41.2 & 42 & 49.4 \\
\hline 4. & $\begin{array}{l}\text { The information about career knowledge } \\
\text { provided in the career guidance has greater } \\
\text { influence on the choice of post-secondary } \\
\text { school training programmes }\end{array}$ & 1 & 1.2 & 3 & 3.5 & 14 & 16.5 & 35 & 41.2 & 32 & 37.6 \\
\hline
\end{tabular}

Source: Field Data, (2021). 
Key; SD - Strongly disagree, D - Disagree, N - Neutral, A - Agree, SA - Strongly agree,

$\mathrm{P}-$ Percentage and $\mathrm{F}$ - Frequency

Table 2 indicate the level of students' agreement to the statements which determine whether career guidance service contribute to the choices of future profession training among secondary school leavers. The findings revealed that 50.6 per cent of students disagreed that teachers interacted with and talk to the students about the world of work and 41.2 per cent of students disagreed that the information about career knowledge provided in the career guidance had greater influence on the choices of post-secondary school training programmes. Likewise, 49.4 per cent of students toughly disagreed that the information they got from their teachers about career helped them to choose their subjects of specialization and 51.8 per cent of students intensely disagreed that career guidance services in public secondary school influenced the choice of future professional training.

\section{Effective contribution of Career guidance service}

This is revealed from Table 1 whereby 57.6 per cent of teacher disagreed that career guidance services in secondary school influenced career choices. Likewise, in Table 2, 51.8 per cent of students strongly disagreed that career guidance services in public secondary school influenced their choice of future professional training. This contrary with Zafar (2019) whose revealed that students who had career guidance made good choices in their future professional training. This shows that career guidance service in secondary schools influences career choices of the students. Therefore, this result means that most of the secondary school leavers depend on the career guidance provided in their former secondary schools in choosing their future professional training. However, career guidance service provided did not influence effectively the choice of their future profession training.

The findings are supported by the information obtained during the interview whereby the head of school $\mathrm{C}$ explained that career guidance service provided in his school was ineffective though it was provided to the students when they were in form four. However, the information provided had a slight impact on the choices of post-secondary education. Therefore, secondary schools should emphasize more on the provision of career guidance service, as indicated when the interviewee was quoted saying;

The service provided in school is not effective, and therefore, the school should revise the way of providing that service so as to improve its effectiveness; though, the information provided has slight influence in the selection of future professional training (Interview $\mathrm{H}_{3}, 2021$ ).

This implies that in secondary school career guidance service is provided though is ineffective due to the challenge encountered. Thus the information provided has a small impact on the choice of future professional training among secondary school leavers. Thus the findings conflicting, with Jain (2017) findings which revealed that career guidance and counselling impact on the process of making decisions on careers among students. This means that career guidance service in school enable student to choose their future professional training.

However, the finding is reliable with the theory of Social Cognitive Career which states that an individual is affected by both internal and external factors in the choice of career, thus, in this scenario career guidance service is regarded as an external factor which impact significantly on one's choice of career. In this perception, it is clear that career guidance service that is provided in secondary schools can be seen as an external factor that influences the choice of careers.

\section{Influence of career guidance information}

This sub-theme was generated from the respondents' findings which determined whether career guidance service influenced the choice of future professional training basing on the information provided during career guidance service. The sub-theme is supported by the findings in Table 1 whereby 52.5 percent of teachers strongly disagreed that the information about career knowledge provided in career guidance services had greater influence on the choice of post-secondary school training programmes.

Likewise, in Table 2 it is indicated that 41.2 per cent of students disagreed that the information about career knowledge provided in the career guidance had greater influence on the choices of post-secondary school training programmes and 49.4 per cent of students intensely disagreed that the information they got from their teacher about career helped them to choose their subjects of specialization. The findings were contrary to that by Gacohi, et. all (2017) which emphasize that the information provided about career knowledge had higher influence on the choice of future professional training. Therefore, in secondary schools, the information provided in career guidance had a slight influence on the choice of future professional training. 
Furthermore, one public secondary school leaver in 2020 commented that there was ineffective career guidance service provided in school which was mainly provided during examination. The interviewee was quoted saying; "The information provided in career guidance service influences slightly the choice of professional training and that's why most of the secondary school leavers join unplanned profession training" (Interviewee 1, 2021).

Also, the findings contrary to the Social Cognitive Theory which guided this study which regard that the information provided could be observed as an external factor which impacted on the students' choices of future professional training. Therefore, the information provided about career guidance contribute slightly to the students' choice of postsecondary school education and professional. However, this study revealed that the information provided in schools about career didn't make the learners aware of the professional training opportunities available and how to join them with the required qualifications. In this sense therefore, career service provided in public secondary school cannot contribute to the choice of students' future profession training.

\section{Association of career guidance service with the present job opportunities.}

This is another sub-theme extracted from the responses made by the participant as indicated in Table 1 whereby 42.4 per cent of teachers strongly disagreed that career guidance services enabled students to associate what they learnt, their abilities and interests with the available job opportunities. Also, in Table 2, 50.6 per cent of the students disagreed that teachers interacted with and talk to the students about the world of work. However, the findings are contrary to Upoalkpajor, (2020) findings which revealed that career guidance service enabled the students to associate their knowledge with the job opportunities available. Therefore, in Magu District, career guidance service provided in public secondary school didn't link student with the employment opportunity available and didn't keep aware the learner about the world of work.

In addition, the information provided through interview with the head of school $\mathrm{B}$ revealed that due to ineffective provision of career guidance service in schools, it was difficult for the secondary school leavers to associate it with the employment opportunities available since they were not aware of the employment opportunities (Interview H2, 2021). This is similar to the information provided by one of the secondary school leavers in 2020 who commented that career guidance service in school was ineffective and that made it difficult for the secondary school leavers to associate what they learnt in school and the job opportunities available in relation to the choice of profession training (Interview 3, 2021). Generally, in this scenario, the study revealed that in Magu District, career guidance provided did not link secondary school leavers to the job opportunities available.

Moreover, the findings are consistent with Social Cognitive Career Theory (SCCT) which observe that an individual is affected by both internal and external factors when making the choice of careers. The association of career guidance service with job employment is an external factor which impacts on personal goals and one's choice of career. Generally, the career guidance service provided in public secondary schools does not link the learner with the employment opportunities available; thus, most of the secondary school leavers enter into unplanned profession training. Therefore, in this sense, effective career guidance service provided in schools should be link the learner with the employment opportunities available.

\section{CONCLUSION AND RECOMMENDATIONS}

The study concludes that career direction services in public secondary schools in Magu district did not contribute to students' choices of their future professional training.

The study recommends that education policy makers should integrate career guidance in the education policies in order to ensure effective implementation of the service in schools. The incorporation of career guidance aspect in the education policies will create room for the policy implementers to do effective implementation of the service.

The study further recommends that the school administrators should ensure that public secondary school teachers get involved effectively in the provision of career guidance services to the students with the aim of helping them to choose their planned future professional training.

Also, the study recommends that the government should ensure provision of career guidance service training to the teachers in order to help the students in their selection of subjects of specialization and finally to choose their future professions appropriately.

\section{REFERENCES}

[1] Azorin, J. F. M. (2016). Mixed methods research: An opportunity to improve our studies and our research skills. European Journal of Management and Business Economics 25(2).37-38

[2] Demir, S. B., \& Pismek, N. (2018). A convergent parallel mixed-methods study of controversial issues in social studies classes: A clash of ideologies. Educational Sciences: 
Theory \& Practice 18(1), 119-149. http://dx.doi.org/10.12738/estp.2018.1.0298

[3] Gacohi, J. N., Sindabi, A. M. \& Chepchieng, M. C. (2017). Influence of Career Information on Choice of Degree Programme among Regular and Self-Sponsored Students in Public Universities, Kenya. Journal of Education and Practice, 8(11), 38-47.

[4] Hooley, T. (2019). International approaches to quality in career guidance. Oslo: Skills Norway.

[5] Hughes, D. (2017). Careers work in England's schools: politics, practices and prospects. British Journal of Guidance \& Counselling, 45(4), 427-440. doi: 10.1080/03069885.2017.1346234.

[6] Jain, P. (2017). Impact of career guidance and counselling on student's career development. International Journal of Research - GRANTHAALAYAH, 5(6), 49-52.

[7] Koech, J., Bitok, J., Rutto, D., Koech, S., Okoth, J.O., Korir, B., \& Ngala, H. (2016). Factors influencing career choices among undergraduate students in public universities in Kenya: A case study of university of Eldoret. International Journal of Contemporary Applied Sciences, 3(2), 50-63.

[8] Loan, D. T. B. \& Van, N. T. (2015). Career Guidance in Secondary Schools - A Literature Review and Strategic Solutions for Vietnamese Rural Areas. American International Journal of Social Science, 4(5), 135-143.

[9] Mabula, N. (2012). Career Services Provision to Secondary School Students in Tanzania: Is it a dream or Reality? International Journal of Learning \& Development, 2(2), 242-257.

[10] Nsamba, S., Kiweewa, J. M., Oonyu, J., \& Otwine, A. (2018). Career Guidance and Counselling in Uganda, Current Developments and Challenges. International Journal of Innovative Research and Development, 7(11), 107-113.

[11] Nyambuya, A. \& Onyango, D. O. (2020). Determinants of Selection of A-Level Subject Combinations for Future Career Choice among Private Secondary School Students in Dodoma City Council, Tanzania. The International Journal of Humanities \& Social Studies, 8(12), 136-145.

[12] Robert, D. (2019). Improving career guidance and counselling practices in building construction in Uganda: A case of Nawanyago technical institute. (Master dissertation, The Kyambogo University Graduate School). Retrieved from https://kyuir.kyu.ac.ug/bitstream/handle/20.500.12504/413/ DDUMBA\%20REPORT\%20EDITED.pdf?sequence $=1$ \&is Allowed $=\mathrm{y}$

[13] Upoalkpajor, J. L. N. (2020). Career Guidance and Its Implications for Students' Career Choices: The Case of Public Senior High Schools in Ghana. Journal of Education Society and Behavioural Science, 33(8), 62-69.

[14] Vaghela, T. R. \& Matimbwa, H. (2019). Determinants of Career Choice Among Secondary Schools Students: Evidence from Selected Secondary Schools in Tanzania. Journal of Business Management and Economic Research, 3(2), 42-55. DOI: 10.29226/TR1001.2019.108

[15] William, N. T. (2016). The impact of career guidance (CG) for career choice (CC) in the Secondary schools of Sepitsi circuit in Lebowakgomo district, Limpopo Province. (Master, dissertation. The University of Limpopo). Retrieved from http://ulspace.ul.ac.za/bitstream/handle/10386/1591

[16] Wong, L. P.W. \& Yuen, M. (2019). Career Guidance and Counseling in Secondary Schools in Hong Kong: A Historical Overview. Journal of Asia Pacific Counseling, 9(1), 1-19. DOI: 10.18401/2019.9.1.1

[17] Yaqoob, U., Arif, F., Samad, M. \& Iqbal, A. (2017). Career counselling and its knowledge among high school students in Pakistan. International Journal of Community Medicine and Public Health, 4(7), 2261-2268. DOI: 10.18203/23946040.ijcmph20172817

[18] Zafar, M. (2019). Career Guidance in Career Planning among Secondary School Students. Asian Journal of Education and Social Studies, 5(1), 1-8. 